\title{
The Impact of Accountability and Transparency on the Management of the Regional Expenditure Budgets of the Kupang District Government
}

\author{
Nonce F. Tuati*, Moni Siahaan, Selfesina Samadara \\ Kupang State Polytechnic \\ Kupang, Indonesia \\ *noncefaridatuati@gmail.com, monijuniati@gmail.com, selfisamadara@gmail.com
}

\begin{abstract}
Accountability and Transparency in Indonesia are issues that have received increasing attention in recent years. This is due in part to the fiscal decentralization from the central government to regional governments as a consequence of regional autonomy, which has led to significant changes in the composition of budget expenditures at the central government and regional governments. One way to achieve government accountability to the public is to use the principle of transparency (openness). In an effort to realize good and clean governance (Good Governance), transparency of the Regional Revenue and Expenditure Budget is one of the important aspects in running local government programs, and in general in an effort to improve the welfare of the local community. This study aims to determine the impact of accountability and transparency, simultaneously and partially, on the management of the Regional Revenue and Expenditure Budget. The sample of this research is the Regional Financial Management officials who carry out the management of the Regional Revenue and Expenditure Budget in all regional work units of the Kupang Regency Government. The sampling technique was purposive sampling. The data in this study are primary data. Data were collected using a questionnaire that was distributed directly to respondents. The analysis method used is a simple linear regression model to test hypotheses partially with the $t$ test and multiple linear regression to test the hypothesis simultaneously with the $F$ test. The results of this research show that transparency and partial accountability through the $t$ test have a significant effect on the management of the Regional Revenue and Expenditure Budget. So that the hypothesis is accepted. Second, jointly (simultaneously) through the $F$ test, transparency and accountability affect the management of the Regional Revenue and Expenditure Budget so that the hypothesis is accepted.
\end{abstract}

Keywords-accountability, transparency, budget, government, region

\section{INTRODUCTION}

\section{A. Background}

Accountability for the Management of the Regional Revenue and Expenditure Budget is an important part of the implementation of regional development. Therefore, in the context of regional infrastructure development, the development program should have been included in the discussion of the regional expenditure budget so that the development program can be financed and implemented, so that development can be directed and controlled. The regional government budget as outlined in the Regional Budget is a means of accountability, management and regional economic policy. Peruzzotti and Smulovitz [1] in his research said that accountability is a series of mechanisms and approaches in which citizens can be held accountable by means other than general elections and bureaucratic procedures.

In an effort to realize good and clean governance (Good Governance), transparency of the Regional Expenditure Budget is one of the important aspects in carrying out local government programs, and in general in an effort to improve the welfare of the local community. The regional government is expected to be able to increase the efficiency of budget utilization in carrying out its programs, in order to meet the people's needs effectively, in this case accountability is a very important issue in maintaining the efficiency and effectiveness of the government budget. This is also stated by Robinson [2] in a study on civil society budget advocacyThe problem in regional financial management and accountability is that there are still many irregularities, irregularities and untruths, and even irregularities in the management and accountability of regional finances and budget realization reports, including the large number of state assets that are managed inappropriately and reported improperly in financial reports which have implications for opinion of the Supreme Audit Agency on regional government financial reports based on Law no. 15 of 2004, regarding the State Financial Management and Responsibility Audit, the Financial Audit Agency provides an opinion on the Regional Government Financial Report in the form of Unqualified Opinion, Qualified Opinion, Adverse Opinion and Not Providing Opinion (Opinion Disclaimer). The presentation of financial statements is very important. Disclosure of this information is a basic element of fiscal transparency and accountability [3]. 
Problems that stand out and affect the fairness of the presentation of financial statements, starting with budgeting that is not in accordance with the provisions of laws and regulations, the implementation of unaccountable expenditure and income realization and improper accountability, which in turn has an impact on financial statements that are not presented fairly in accordance with government accounting standards. This is according to Yusuf Ateh, the Head of Accountability in the Office of the State Minister for State Apparatus Empowerment, because until now the Indonesian Government has not demonstrated its accountability capability, even though one of the characteristics of an accountable government is that it has measurements, objectives and targets for the proposed program. In this problem, the governance approach needs to be studied as research by Hajer and Versteeg [4] and White [5] who explain the many understandings of accountability.

The purpose of this study is to determine the impact of accountability and transparency, simultaneously and partially, on the Regional Budget Management. This research is important to do with regard to accountability where the public has the right to know the policies taken by the parties they trust, in this case the Government. The government must provide the information needed in managerial processes, such as planning, budgeting, implementing, monitoring, and evaluating Government performance. Several studies on the impact of accountability and transparency have been conducted. Based on the findings of Goetz and Jenkins [6], Hladchenko [7] and Kolstad and Wiig [8] it is said that accountability and transparency are very important in government budget management. Based on the description above, the researcher feels the need to conduct research on the impact of accountability and transparency on the management of the Kupang district government budget

\section{B. Formulation of the Problem}

- Does Accountability Affect the Management of the Kupang Regency Government's Regional Budget?

- Does Transparency Affect the Management of the Kupang Regency Government's Regional Budget?

- Does Accountability and Transparency Affect the Management of the Local Government Budget in Kupang Regency?

\section{RESEARCH METHODS}

\section{A. Type and Research Design}

Based on the characteristics of this study, this type of research is a causal research with quantitative methods with a descriptive approach. Researchers use this research to provide empirical evidence from the analysis of the effect of transparency and accountability on the management of the Regional Expenditure Budget.

\section{B. Research Object}

The research objects of this study were all SKPDs of Kupang Regency Government Offices.

\section{Data Collection Techniques}

The data collection technique used in this study was a questionnaire.

\section{Population and Research Sample}

The population in this study are all officials who carry out regional financial management. The sample of this research is Regional Financial Management officials who carry out APBD management in all SKPDs of Kupang Regency Government Offices. The sampling technique was purposive sampling with a total of 99 respondents. The data in this study are primary data. Data were collected using a questionnaire that was distributed directly to respondents.

\section{E. Data Analysis Methods}

The data analysis method used includes the classic assumption deviation test and multiple regression analysis. The classic assumption deviation test consists of multicollinearity test, heteroscedasticity test, autocorrelation test and normality test. While the regression equation model of this research is: $Y$ $=\mathrm{a}+\mathrm{b} 1 \mathrm{X} 1+\mathrm{b} 2 \mathrm{X} 2+\mathrm{e}$, where: $\mathrm{Y}=$ Budget Management, $\mathrm{X} 1$ $=$ accountability, $\mathrm{X} 2=$ transparency, $\mathrm{a}=$ constant $\mathrm{b} 1, \mathrm{~b} 2=$ regression coefficient.

\section{RESULTS AND DISCUSSION}

\section{A. Classic Assumption Test}

1) Normality test: The normality test used in this study is the Kolmogrov-Smirnov test with a significance level of 0.05 , if significant $>0.05$, the data is said to be normally distributed. based on the results of normality testing by looking at the Kolmogrov Smirnov value, the significance value ( $\mathrm{P}$-Value) is $0.773>0.05$. Thus it can be concluded that the regression model is feasible because it meets the assumption of normality or it can be said that the distribution of research data is normally distribut.

2) Multicollinearity test: In this study, to determine whether there is a multicollinearity problem or not, the Tolerance Value or Variance Inflation Factor (VIF) method is used, provided that the VIF value is around 1 to 10 , as well as the tolerance value> 0.1 . Based on the results of this study, it can be seen that each independent variable has a tolerance of more than 0.1 and has a VIF value of less than 10 , so it can be concluded that there is no multicollinearity symptom in the regression model.

3) Heteroscedasticity test: The test used in this study used the Glejser test, namely regressing the absolute residual value by seeing its significance on the $5 \%$ degree of confidence. If the significance value is $>0.05$ then heteroscedasticity does not 
occur. Based on the results of the analysis in this study, it can be seen that each independent variable has a significance value greater than 0.05 , thus indicating that each variable does not contain heteroscedasticity, thus fulfilling the requirements in the regression analysis.

4) Hypothesis testing: This study describes a relationship in which one or more variables (variables independent) affects other variables (independent variables). Hence the researcher using multiple regression analysis to test the hypothesis in this study. In multiple linear regression analysis, in addition to measuring the effect of independent variables on variables dependent also indicates the direction of the influence. Data management will be done with using the SPSS application tool. The formulations used are:

$$
\mathrm{Y}=\mathrm{a}+\mathrm{b} 1 \mathrm{X} 1+\mathrm{b} 2 \mathrm{X} 2+\mathrm{e}
$$

Information :

\section{Y: Regional Budget Management}

\section{X1: Accountability Variable}

X2: Variable Transparency

\section{a: Konstansta}

b1 b2: Regression coefficients of the variables X1 and X2

\section{e: Residual error (error)}

This equation is then analyzed using a significance level of $5 \%(\alpha=0.0)$.

\section{B. Multiple Regression Analysis}

Multiple linear regression test aims to determine the direction of the relationship between the independent variable and the dependent variable whether positive or negative.

1) T test (Partial regression coefficient test): The $t$ test is used to determine whether the independent variable partially affects the dependent variable or not. The results of the t test obtained (partial test) Testing the coefficient of the Accountability variable (b1) The test steps are as follows: Determine the null hypothesis and the alternative hypothesis Ho: $b 1=0$ (Partial accountability has no effect on the Management of the Kupang Regency Regional Budget. ). Ha: $\mathrm{b} 1 \neq 0$ (Accountability partially affects the Management of the Regional Expenditure Budget at the Government of Kupang Regency. Determining $t$ count obtained $t$ count is 2.279. Determining t table using a significance level of 0.0 The value of $t$ table can be seen in the statistical table with a significance of 0.05 and degrees of freedom (df) nk-1 or $37-2-1=34$. With a 2-sided test the results obtained for t table are 2.027 /-2.027. Criteria for testing Ho is accepted if- $t$ count $\geq-t$ table or $t$ count $\leq \mathrm{t}$ table Ho is rejected if- $\mathrm{t}$ count $<-\mathrm{t}$ table or $\mathrm{t}$ count $>\mathrm{t}$ table Comparing $t$ count with $t$ table Value of $t$ count $>t$ table (2.279> 2,027), then Ho is rejected, Determination Area of Ho
Effect of X1 on Y - 2,027+2,027 2,279, Making conclusions Because the value of $t$ count $>t$ table $(2,279>2,027)$, then Ho is rejected, meaning that accountability partially affects the Management of the Regional Budget in the Government $\mathrm{Ka}$ Kupang regency. The $t$ value is positive, meaning that it has a positive effect, namely the increased accountability will improve financial management. Testing of the Transparency Variable Coefficient (b2) The test steps are as follows: Determine the null hypothesis and the alternative hypothesis Ho: $b 2=0$ (Partially transparency has no effect on the Regional Budget Management of the Kupang Regency Government). Ha: $b 2 \neq 0$ (Transparency partially affects the Management of the Regional Expenditure Budget in the Kupang Regency Government) Determining the t count Based on the table above, it is obtained t count of 3.244 Determining $t$ table using a significance level of 0.05 . The value of $t$ table can be seen in statistical table with a significance of 0.05 and degrees of freedom (df) nk-1 or 37-2-1 = 34. With a 2 -sided test the results obtained for t-table of $2.027 /-2.027$. Criteria for testing Ho is accepted if- $\mathrm{t}$ count $\geq-\mathrm{t}$ table or $\mathrm{t}$ count $\leq \mathrm{t}$ table Ho is rejected if-t count <-t table or $t$ count $>t$ table Comparing $t$ count with $t$ table Value $t$ count $>t$ table $(3,244>$ 2,027), then Ho is rejected.

Because the value of tcount> ttable (3.244> 2.027), Ho is rejected, meaning that transparency partially affects the Management of the Regional Expenditure Budget at the Kupang Regency Government. Financial management Test F (Simultaneous Regression Coefficient Test) The F test is used to determine whether the independent variable simultaneously affects the dependent variable or not. alternatives Ho: b1, b2 = (This means that accountability and transparency partially do not affect the Management of the Regional Expenditure Budget in the Government of Kupang Regency Ha: b1, b2 $\neq 0$ (This means that accountability and transparency partially affect the Management of the Regional Budget in the Government of Peme r command of Kupang Regency Determining Fcount, it is obtained Fcount of 32.605 Determining F table F can be seen in the statistical table attachment, using a significance level of 0.05 , with df 1 (number of variables -1 ) or $3-1=2$ and $\mathrm{df} 2$ (nk-1) or 37-2-1 = 34. The results obtained for F table is 3.276. Testing criteria Ho is accepted if Fcount $\leq$ Ftable Ho is rejected if Fcount> Ftable Compares tcount with ttable. Fcount value> Ftable (32.605> 3.276), then Ho rejected 3,276 32,605. The Determination Area of Ho in the F Test - Making a conclusion Because Fcount> Ftable (32.605> 3.276), then Ho is rejected, meaning that accountability and transparency partially affect the Regional Budget Management in the Kupang Regency Government. Analysis of the coefficient of determination ( $R$ Square) Value the coefficient of determination shows how much the percentage of the regression model is able to explain the dependent variable. The limit value of $\mathrm{R} 2$ is $0 \leq \mathrm{R} 2 \geq 1$ so that if R2 is equal to zero (0) it means that the dependent variable cannot be explained by the independent variable simultaneously, whereas if R2 is equal to 1 it means that the independent variable can explain the dependent variable 
simultaneously. Determination ( $\mathrm{R} 2$ ), the $\mathrm{R} 2$ value is 0.657 $(65.7 \%)$. This shows that the variation of the independent variables used in the model (accountability and transparency) is able to explain $65.7 \%$ of the variation in financial management variables, and the rest is explained by other variables not included in this research model.

\section{CONCLUSION AND SUGGESTION}

\section{A. Conclusion}

Based on the analysis conducted previously, there are several things that can be concluded in this study. First, transparency and accountability partially through the $t$ test have a significant effect on the management of the Regional Expenditure Budget so that the hypothesis is accepted. Second, jointly (simultaneously) through the $F$ test, transparency and accountability affect the Regional Budget Management so that the hypothesis is accepted. This is indicated by the $t$ test which shows the value of $t$ count $>t$ table (2.279> 2.027), so that Ho is rejected. The $t$ value is positive, meaning that it has a positive effect, namely the increased accountability will improve financial management. Accountability has a positive and significant effect on the Regional Budget Management of the Kupang Regency Government. Accountability is one of the main elements of the realization of Good Corporate Governance that has been implemented so that the public can judge whether the government is working economically, efficiently and effectively. Transparency has a positive and significant effect on the Regional Budget Management of the Kupang Regency Government, where the budget must be able to provide clear information about the objectives, targets, results, and benefits that the community gets from an activity or project that is budgeted. Transparency partially affects the Regional Budget Management of the Kupang Regency Government. This is indicated by the t-test, where the values> $t$ table (3.244> 2.027) are obtained, so that Ho is rejected. The $t$ value is positive, meaning that it has a positive effect, namely increasing transparency, so it will improve financial management. Accountability and transparency partially affect the Management of the Regional Budget in the Government of Kupang Regency. This is shown by the F test which shows that the value of Fcount> Ftable (32.605> 3.276), so that Ho is rejected.

\section{B. Suggestion}

To realize good governance in Kupang Regency, a synergy is needed between components in good governance, namely government, society and the private sector. So that the implementation of accountability and transparency is carried out properly, then:

- It takes active participation from the public and the private sector to respond to information on local government accountability reports that have been submitted to public. Because with the response from the community and private sector, it can be made evaluation in the implementation of governance and development in Kupang Regency.

- For further research, it is expected to add or expand the collection location samples that do not only focus on one district, but should be able to do in several regions / cities in order to obtain more respondents or samples, such that the generalizability of the research results is better.

- For the next researcher can add other independent variables, so that it is expected provide better, complete, and useful research results.

\section{REFERENCES}

[1] E. Peruzzotti and C. Smulovitz, "Social Accountability: An Introduction," in E. Peruzzotti and C. Smulovitz, (eds) Enforcing the Rule of Law: Social Accountability in the New Latin American Democracies, Pittsburgh, PA: University of Pittsburgh, 2006

[2] M. Robinson, Budget Analysis and Policy Advocacy: The Role of Non Governmental Public Action. IDS Working Paper 279, Brighton: Institute of Development Studies, 2006.

[3] J. Diamond "Performance Budgeting - Is Accrual Accounting 89 Required?" IMF Working Paper. Fiscal Affairs Department, 2002.

[4] M. Hajer and W. Versteeg, "Performing Governance through Networks,” European Political Science, no. (4), pp. 340-347, 2005.

[5] H. White, Theory-Based Impact Evaluation: Principles and Practice Working Paper 3, Delhi: International Initiative for Impact Evaluation, 2009

[6] A. Goetz and R. Jenkins, Reinventing Accountability. New York: Palgrave Macmillan, 2005.

[7] L. Hladchenko, "Government Financial Accountability and Transparency in the Digital World," ICTERI 2016, Kyiv, Ukraine, June 21-24, pp. 477-483, 2016

[8] I. Kolstad and A. Wiig, "Is Transparency the Key to Reducing Corruption in Resource-Rich Countries?" World Development, vol. 37 , no. (3), pp. 521-532, 2009 . 